\title{
Alberta's Métis Settlements and the Co-Management Agreement
}

\author{
Wayne Renke
}

The many Metis leaders who had fought for nearly a decade to have land set aside for the exclusive benefit of their people had envisaged the Settlements as a means by which the Metis would gain control of their own destiny .... [T] hrough the constant efforts of the various leaders, the Settlements have gradually taken over increasing control of their own affairs. Their goal is to create self-reliant, secure, and prosperous communities built on the strengths of Land and Culture. However the manner in which this goal is eventually achieved is perhaps more important than the goal itself .... Outside resources are a necessary part of settlement growth, however it is essential that the application of these resources be controlled and directed by the community through their local government framework. ${ }^{1}$

On 16 May 2013, the Alberta Government and the Metis Settlements General Council (MSGC) announced that a new "Co-Management Agreement" (CMA) had been achieved. ${ }^{2}$ The new agreement $(2013 \mathrm{CMA})^{3}$ amends the original CMA (1990 CMA) set out in Schedule 3 to the Metis Settlements Act (MSA). ${ }^{4}$ The new agreement has been viewed very positively by the MSGC:

"The Metis Settlements General Council is excited about the co-management agreement," said Randy Hardy, Council President.

"The potential revenues and economic opportunities generated by this agreement are an essential component to the long term sustainability of the Settlements. This signing marks yet another historic day in the continuing partnership between the Government of Alberta and the Metis Settlements."

\footnotetext{
"It allows us to get in on the real action, on the business part of the monies - that is where the lion's share is," Metis Settlements General Council president Randy Hardy said.

"We can pick and choose our investors (and) partners and we can move at the pace that communities feel comfortable."
}

Generally, the CMA establishes a framework whereby the MSGC and a Métis Settlement affected by a proposed mineral development may limit, benefit from, and participate in operations on Settlement lands, even though mineral ownership remains vested in the Province.

Is President Hardy's enthusiasm for the 2013 CMA justified? In my view, it is. This conclusion will be supported by (A) an examination of the development of the "continuing partnership between the Government of Alberta and the Metis Settlements" that provides the setting for the CMA; (B) an account of the operation of the 2013 CMA; and (C) an assessment of the 2013 CMA. ${ }^{7}$ I hope to show that the 2013 CMA contributes to the goal identified by Elmer Ghostkeeper in the epigraph - "to create self-reliant, secure, and prosperous communities built on the strengths of Land and Culture," under the control and direction of Métis Settlement governance. 


\section{A. The continuing partnership}

The "continuing partnership between the Government of Alberta and the Metis Settlements" has four key elements. First, the governmental partner is Alberta - not Canada. Second, the Métis partners are (collectively) the Métis Settlements - not all Alberta Métis people (whether on- or off-Settlement, rural or urban). Third, the Province, not the Métis Settlements, owns the minerals beneath Settlement lands. Fourth, the Province and the Métis Settlements now coordinate the development of these resources. The features of this partnership evolved over about 60 years.

The partnership's origins lie in the lack of partnership with the federal Crown and the failure of the scrip system. ${ }^{8}$ While the Métis are one of Canada's founding aboriginal peoples, the federal Crown

did not apply to the Métis its policy of treating with the Indians and establishing [reserves] and other benefits in exchange for lands. In some regions, it adopted a scrip system that accorded allotments of land to individual Métis. However, Métis communities were not given a collective reservation or land base; they did not enjoy the protections of the Indian Act or any equivalent. Although widely recognized as a culturally distinct Aboriginal people living in culturally distinct communities, the law remained blind to the unique history of the Métis and their unique needs. ${ }^{9}$

Scrip issued to Métis heads of families "passed readily and cheaply into the hands of speculators," leaving these families landless. ${ }^{10}$ By the 1930s, the Métis community in Alberta was in a "desperate condition." ${ }^{11}$ Ottawa offered no solutions. The Métis leadership pressured the Province, which - fortunately - listened. ${ }^{12}$ In 1934, the United Farmers of Alberta government established a commission chaired by Justice Albert Freeman Ewing to investigate "the health, education, relief and general welfare of the halfbreed population"13 The federal Crown refused to participate in the proceedings. ${ }^{14}$

In addition to supporting Alberta's partnership with the Métis, the Ewing Commission rec- ommendations previewed the land-based but Crown-owned minerals features of the partnership. The overall aim of the Commission and Métis leadership was Métis self-sufficiency, but the Commission conceived a viable future for the Métis only through farming and connected arts. ${ }^{15}$ Farming requires land. The Commission therefore recommended that farming colonies be established. ${ }^{16}$ Since the transition from traditional hunting, trapping, and fishing to farming would not be immediate, it recommended (e.g.) that colonies be established near lakes permitting fishing. ${ }^{17}$ The Commission understood that some Métis could make a good living hunting and trapping, and so could be assigned lands for these purposes. ${ }^{18}$ The Commission did not recommend granting lands in fee simple to individuals or Métis organizations. Title to colony lands would remain with the Provincial Crown. ${ }^{19}$ By implication, mineral interests would remain with Alberta.

In 1938, following consultation with Métis leaders, the new Social Credit government responded to the Ewing Commission's recommendations through the Metis Population Betterment $A c t,{ }^{20}$ later renamed the Metis Betterment Act $(M B A) .{ }^{21}$ The $M B A$ provided for the establishment of Métis settlement areas and settlement associations, but lands were held by the Crown. The Act dealt with surface concerns only, such as timber development, and emphasized the use of lands for farming. ${ }^{22}$ Recognition of Métis interests in relation to minerals awaited the resolution of future litigation.

The casus belli was a 1960 regulation made under the authority of the $M B A$ - the "Regulations Relating to the Administration of the Funds of the Metis Settlement Associations." ${ }^{23}$ Section 1 of its Schedule provided that "all moneys accrued or hereafter accruing from the sources hereinafter set out shall be credited to a trust account, known as the Metis Population Betterment Trust Account Part I"; and included as sources "moneys received by way of compensation from oil companies for use of surface rights on unoccupied lands, and all moneys received from the sale or lease of any other of the natural resources of the said areas." ${ }^{24}$ The Province paid surface-related 
revenues into the trust account, but not mineral resource revenues. The Métis Settlements took the position that the subsurface was set aside for their benefit and subsurface resource revenues should therefore have been paid into the trust account. First Nations received the benefit of subsurface development on their lands; so too should the Métis. ${ }^{25}$

Litigation was commenced against the Province on 29 July 1968, seeking "declarations that mines and minerals were included in the provincial lands set aside for the associations, and that all moneys accrued or hereafter accruing from the sale, lease or rental of the petroleum and natural gas rights in the said lands should be held on behalf and for the benefit of the respective associations." ${ }^{26}$ The statement of claim was struck out on application before Justice Riley, however, because of misnomer - the Attorney General for Alberta was improperly named as defendant. Justice Riley took this step reluctantly:

The case at bar graphically illustrates rule by the executive branch of government, the administrative branch, and the bureaucrats; the defiance of those branches of "the rule of law," all principles of "equity" and fairness," resulting in subjugation of the courts.

It goes without saying that if the plaintiffs can find some method of properly bringing the matter before the courts this decision does not fetter them in any way and is without prejudice to their rights so to do. ${ }^{27}$

In 1977 a class action and an action by the Alberta Federation of Métis Settlements (the Federation $)^{28}$ were commenced against the Province; the actions were eventually joined. Some \$30 million dollars was sought for lost subsurface resource revenues. ${ }^{29}$

A remarkable and unfortunate litigation misstep resulted in the Province being turned towards recognition of Métis mineral interests. The Province's counsel learned that some "Government files" bearing on the proceedings were in the custody of Settlement Association offices. To prepare for Examinations for Discovery and to prepare the Province's Affidavit of Documents, counsel requested that all Provincial files be brought to a central location for review. ${ }^{30}$ On 18 June 1979, between 8:15 am and 9:30 am, members of the Province's Metis Development Branch attended at the eight Settlement offices to seize "Government files." 31 The Federation lodged a complaint with the Provincial Ombudsman, Dr Randall E. Ivany. The Ombudsman found that the Province was wrong to have removed the files; ${ }^{32}$ among his recommendations were that the Department of Social Services and Community Health (the Departmental home for the Branch) apologize to the Métis Settlements; the Province establish a joint committee with the Métis Settlements to review and reconsider the MBA; and "efforts towards speedy resolution of the minerals rights issue" be maintained. ${ }^{33}$

In 1982, the Province responded to the Ombudsman's recommendations by establishing a Joint Government-Metis Committee, chaired by Dr. Grant MacEwan, to review the Metis Betterment Act and regulations (the MacEwan Committee). ${ }^{34}$ The MacEwan Committee Report reflected the new constitutional reality that Métis rights - as aboriginal rights - had received express constitutional protection in ss 25 and 35 of the Constitution Act, 1982. The MacEwan Committee Report made strong recommendations in support of Métis self-government. On lands issues, the Committee observed that Provincial control "cast a pall over Metis land development efforts." ${ }^{35}$ It recommended that fee simple title to the Métis settlement areas be transferred to the Métis settlements - but not mines and minerals rights:

44(2): Issues relating to the ownership or benefits from mines and minerals are presently before the Courts. The settlements and the Government have, so far, agreed to let the Courts resolve these matters.

(3) Subject to subsection (2), natural resources should be vested in the settlements. ${ }^{36}$

Following further discussion with the Métis leadership, the Province committed to reform Provincial- Métis relations in light of the MacEwan Committee recommendations. On 3 June 1985, on the motion of Premier Peter Lougheed, the Alberta Legislature unanimously passed 
Resolution 18, endorsing commitments of the Alberta Government that included granting existing settlement lands to Metis Settlement Associations in fee simple - but "reserving thereout all mines and minerals" and "without prejudice" to the ongoing litigation; and, once a revised Metis Betterment Act had been enacted, amending the Alberta Act to grant an estate in fee simple in existing Metis settlement lands to the Metis Settlement Associations. Significant further discussions between the Province and the Métis leadership ensued ${ }^{37}$ and substantial consultation took place within Settlement communities. ${ }^{38}$

On 1 July 1989, the Province and the Federation entered into the Alberta-Metis Settlements Accord, resolving outstanding issues. ${ }^{39}$ The legislation proceeding from the Accord (inter alia) ${ }^{40}$

(a) "settled" the litigation against the Province; ${ }^{41}$

(b) established a $\$ 310$ million, 17-year funding commitment by the Province to the Métis Settlements; ${ }^{42}$

(c) provided a framework for selfgovernance for the Métis Settlements; ${ }^{43}$

(d) confirmed the corporate status and powers of the MSGC and Métis Settlements; ${ }^{44}$

(e) confirmed that the Province would grant about 1.24 million acres of land to the MSGC in fee simple, by way of Letters Patent - this would form the land base for each of the eight Métis Settlements, but would not include mines and minerals rights; ${ }^{45}$

(f) established protection for the Métis Settlements' land base in the Constitution of Alberta; ${ }^{46}$ and

(g) established the CMA.

Thus, the elements of the "continuing partnership" were confirmed - the Province and the Settlements (with their land-base) as partners, with the surface owned in fee simple by the MSGC and minerals owned by the Province, but with minerals beneath Settlement lands now subject to the CMA.

\section{B. The co-management agreement}

The "co-management" aspect of the CMA is precisely focused. It establishes serial control over phases of the tenure process - i.e., the process by which industry obtains rights to explore for and exploit "Minerals." ${ }^{47}$ It does not provide for "co"management, in the sense of joint and cooperative ongoing regulatory supervision of industry by the Province and the Métis Settlements. ${ }^{48}$ The CMA nonetheless provides Métis Settlements with significant control over mineral resource development, despite the Province's reservation of mineral title. ${ }^{49}$ To expose that significance, the CMA process must be contrasted with "ordinary" public posting and direct purchase processes.

\section{1. "Ordinary" process}

Tenure processes are governed by the Mines and Minerals $A c t^{50}$ and regulations, including the Petroleum and Natural Gas Tenure Regulation (respecting conventional oil and gas tenures $)^{51}$ and the Oil Sands Tenure Regulation, 2010 (respecting oil sands tenures), ${ }^{52}$ and Alberta Energy policies and practices. The key features of oil sands and conventional oil and gas tenure processes are the same.

Usually, a project proponent initiates the tenure process by making a posting request to Alberta Energy through its electronic transfer system. ${ }^{53}$ The initiative lies with industry rather than government since industry knows what it wants; government is spared posting unwanted lands.

Posting requests are reviewed by the interdepartmental Crown Mineral Disposition Review Committee (CMDRC), which identifies significant surface issues entailed by development, and may recommend against disposition or that disposition be permitted only on specified conditions. ${ }^{54}$ The Minister of Energy decides whether lands will be posted. Alberta does not engage in consultation with aboriginal peoples before the posting decision is made. ${ }^{55}$

Sets of lands are posted at regular intervals in public offerings through the Alberta Energy website. ${ }^{56}$ Public offering documents provide 
particulars concerning the lands and the interests available, including surface issues identified by the CMDRC. ${ }^{57}$ The sole bidding variable is the "bonus" or upfront cash payment, which must exceed a specified minimum amount. Industry does not bid on the basis of (e.g.) royalty percentages or rental rates, or the value of work to be done respecting lands. The Minister awards an agreement for particular lands to the highest bidder. The results of public offerings are reported on the Alberta Energy website.

In very limited circumstances, a proponent may request a "direct purchase." This is not an offer actually to purchase mines and minerals, but a request for the issuance of rights outside the public offering process. Alberta Energy will entertain a request for a "direct purchase" in three circumstances: ${ }^{58}$

(i) if a spacing unit includes both freehold and Crown rights, the Crown rights concern less than $50 \%$ of the smallest applicable spacing unit for the land, and the applicant controls the freehold rights, whether as title-holder or leaseholder (i.e., the applicant seeks control of all of the relevant rights in the unit);

(ii) the applicant has an agreement granting rights to a "single substance" (natural gas or petroleum) and seeks the corresponding rights (petroleum or natural gas); or

(iii) the applicant has an agreement granting oil sands rights and seeks to purchase "the associated natural gas rights for the available zones that match [the] oil sands rights," ${ }^{9}$ or holds a petroleum and natural gas agreement but seeks associated oil sands rights. ${ }^{60}$

\section{CMA process: Métis Settlement Organizations}

The CMA grants roles in the tenure process only to specified Métis Settlement organizations. The 1990 CMA provided for the appointment of fivemember "Metis Settlement Access Committees" to participate in the tenure process: (a) one member to be appointed by the Minister,

(b) one member to be appointed by the Alberta Energy Regulator, which member may be an employee of the Regulator but not a director of the Regulator,

(c) one member to be appointed by the Settlement Corporation for the Settlement Area in respect of which the committee is being appointed,

(d) one member to be appointed by the General Council, and

(e) one member to be appointed by the Commissioner or, if the Commissioner ceases to be appointed, by mutual agreement of the other four members, such member to be chair of the committee. ${ }^{61}$

Besides being administratively clumsy, the committee composition perpetuated governmental involvement in Métis resource decisions. This committee was eliminated by the 2013 CMA. The MSGC and the Affected Settlement Council - i.e., the Settlement Council of the Settlement Area in which the relevant minerals are located (ASC) - are now the only two decision-making Métis organizations under the CMA.

The 2013 CMA introduces a third type of Métis organization, not contemplated by the 1990 CMA - an "Affected Settlement Owned Corporation" - "a body corporate incorporated pursuant to, and carrying on business in compliance with, the laws of Alberta, and which is wholly owned, both legally and beneficially, by the Affected Settlement Council (s101) (ASO Corp). ${ }^{62}$ An ASO Corp has a special status in both the posting and direct purchase processes. It must be wholly owned by the requisite Settlement Council - there could be no other equity investors. The owner must be the Settlement Council for the area where the relevant Minerals are located - it is not enough for the owner simply to be a Settlement Council, not connected to that area.

\section{CMA process: public posting}

The first two ordinary public offering steps - initiation by posting request and CMDRC review ${ }^{63}$ - are not altered by the CMA. Further, the Minister retains the discretion not to post based on 
a CMDRC recommendation: s 201 of the 2013 CMA refers to "Minerals that the Minister is willing to post." The CMA alters the ordinary posting process in three ways. First, a "surface veto" is inserted before the posting decision; second, bidding involves more than a bonus - bidders must address specified Métis interests; third, negotiation and "agreement veto" processes are inserted after highest bidders have been identified.

\section{(a) the "Surface Veto"}

Section 304 of the 1990 CMA provided for a "surface veto," allowing the relevant Métis organizations to recommend that lands not be posted. A veto is maintained in the 2013 CMA. Under s 201 ("for Minerals that the Minister is willing to post"), the Minister shall refer a posting request to the MSGC. The MSGC consults with the ASC. Within 15 days after the referral, the MSGC shall recommend to the Minister that the Minerals be posted or that the posting request be denied (s. 202). If the recommendation is to deny posting, the Minister may nonetheless issue rights through the public offering process respecting the Minerals (s 205). However, the offering must be on notice that access to Settlement lands may not be granted (s 204). ${ }^{64}$ Rejecting access would put the MSGC and ASC at some economic risk. Directional drilling could permit access from non-Settlement lands to minerals beneath Settlement lands, leaving no CMA benefits for the MSGC and ASC. The constraining factor from industry's perspective would be cost.

\section{(b) the Bidding Process and Métis Benefits}

If the MSGC recommends posting, the Minister shall include the Minerals in the next public offering, together with the General Terms and Conditions (s. 203). ${ }^{65}$ The General Terms and Conditions document posted on the MSGC website describes "Standard Commitments" (such as "[e]nsure the protection of the environment in the Settlement Area in accordance with provincial standards and Settlement bylaws;" and "[c]onduct operations in a way that maintains the social and cultural order of the Settlement Area") and "Negotiated Commitments:"
1. Recognize the General Council's right to an overriding royalty, as provided for in the Co-Management Agreement.

2. Confirm the General Council's right to a participation option, as provided for in the Co-Management Agreement.

3. Employ, train, and provide business opportunities to Settlement members, to an extent that is practical, during the construction, operation, reclamation and abandonment phases of its operations in the Settlement Area.

4. Such other matters as may be negotiated between the parties. ${ }^{66}$

The 2013 approach simplifies and generalizes a process established under s 303 of the 1990 CMA. The 1990 CMA and the 2013 CMA refer to similar terms and conditions. ${ }^{67}$ The 1990 procedure, though, did not require that these sorts of terms and conditions be put to bidders. ${ }^{68} \mathrm{Bid}$ ders, then, did not necessarily address these matters. The 2013 CMA requires that bidders include with bids a "Metis Settlement Benefit Proposal"69 which responds, in particular, to the "Negotiated Commitments" indicated in the General Terms and Conditions. ${ }^{70}$ Two of the "Negotiated Commitments," the Overriding Royalty and the Participation Option, warrant some elaboration.

Since Alberta is the minerals owner, absent any supplementary arrangements, Alberta - not any Métis organization - would be entitled to receive royalties. But through an "Overriding Royalty," the MSGC and ASC may receive royalties. The "Overriding Royalty" is "a right ... to receive a share of the portion of production, or of the value of the portion of production ... that remains after payment of royalty to the Minister in relation to such production" (s. 101; this definition tracks the 1990 CMA definition). The Benefits Proposal document warns that "absolutely no [other] deductions" are permitted. ${ }^{71}$ The Overriding Royalty is not a working interest, and neither permits profit-sharing beyond the terms of the royalty nor entitles to any participation in the operation of the leased lands. The payee of the Overriding Royalty is the MSGC, not the ASC. The revenues, however, are shared between the MSGC and the ASC. Pursuant to the MSGC Oil and Gas Resource Sharing Policy, 
10(1) Any and all revenues resulting from any Overriding Royalty under the Comanagement Agreement of 3\%, on a production value of $100 \%$ shall be the property of the Metis Settlements General Council.

(2) Any revenues resulting from any Overriding Royalty over 3\%, on a production value of $100 \%$ shall be paid to the affected Settlement Corporation. ${ }^{72}$

A "Participation Option" - which may be combined with an Overriding Royalty - involves the transfer of a working interest to the MSGC. It is "an option reserved in a Development Agreement to [the MSGC] that allows the [MSGC] to obtain from [the successful bidder] a specified undivided interest in the Resource Agreement of up to $25 \%$ with the option to negotiate a greater interest in circumstances where both parties agree" (s. 101). Formerly, participation was capped at $25 \%{ }^{73}$ Participation entails proportional sharing of development and marketing costs and proportional sharing of profits. Participation would require a form of investment by the MSGC. The Participation Option is reserved to the MSGC, but pursuant to MSGC policy, the MSGC's interest is shared with the ASC:

9(1) Subject to paragraph 9(2) below, the Participation Option shall be shared equally between the MSGC and the affected Settlement.

(2) Where the MSGC or an affected Settlement does not exercise all or only part of its share of the Participation Option, the MSGC or the affected Settlement, as the case may be, has the right of first refusal to take up the remainder of the Participation Option. ${ }^{74}$

An ASC's "share of a Participation Option" cannot be assigned or converted into another interest. $^{75}$

\section{(c) Post-Bidding Negotiation and the Agreement Veto"}

Once the bidding process is complete, if one or more bidders have met bid requirements, one of two processes may be engaged. If the top bidder (highest bonus payment) is an ASO Corp, the Minister shall provide the name of that bidder and its Benefit Proposals to the MSGC. ${ }^{76}$ If the top bidder is not an ASO Corp but otherwise meets the conditions for qualification as an "Eligible Bidder," 77 the Minister shall provide to the MSGC the names and Benefits Proposals of the bidder who made the highest bonus payment and the bidders who made a bonus payment "that is at least $75 \%$ of [the] highest bonus payment". ${ }^{78}$ That is, several bidders may participate in negotiations. This multi-party approach is a 2013 innovation - under the 1990 CMA, only the top bidder moved to the negotiation stage. ${ }^{79}$

The MSGC and the ASC may then negotiate with these bidders respecting the negotiable items referred to in the General Terms and Conditions (ss $208-210){ }^{80}$ Within 15 days after being provided with the names, the MSGC and the ASC must notify the Minister that either (a) the MSGC and the ASC have entered into a Development Agreement with one of the bidders; or (b) all bids should be rejected (s. 214). A Development Agreement "sets out the rights and obligations of [the] parties with regard to the General Terms and Conditions, surface access, and exploration for and development of Minerals" (s. 101).

If a deal is made, the Minister shall issue a Resource Agreement to the bidder who is a party to the Development Agreement (s. 215). If the Minister does not receive notice of the outcome of consultations within 15 days or if the Minister is notified that all bids should be rejected, the Minister shall reject all bids - a veto over development is preserved. Some additional discretionary deterrence for intransigence is provided: if the "veto" is exercised, the Minister "may defer all further posting of the Minerals ... for a period of time to be determined by the Minister" (s. 217). During a deferral period, neither Alberta nor the MSGC would draw revenues from the Minerals.

\section{CMA Process: Direct Purchase}

The 2013 CMA precludes non-Métis-connected proponents and Métis-connected corporations not meeting the ASO Corp definition ${ }^{81}$ from acquiring Métis Settlement mineral rights through direct purchase. Non-Métis-connected 
proponents (at least) may still acquire interests through the public offering process, as modified by the CMA. ${ }^{82}$

An ASO Corp, however, may request a direct purchase (unless the lands are already subject to the posting request procedure, in which case that procedure must be followed (s 302)).

An ASO Corp's "Direct Purchase Request", submitted to the Minister, must be supported by the MSGC and the ASC (s 301). Within 60 days of receiving the request, the Minister must issue an offer to the ASO Corp. including

(a) the purchase price,

(b) any special provisions determined by the Minister,

(c) General Terms and Conditions, and

(d) any additional terms and conditions recommended by the CMDRC (s. 303).

The ASO Corp then has 10 days to accept the offer, which requires the negotiation of a Development Agreement with the MSGC and the ASC, payment of required amounts, and provision of certain waivers and releases (s 304). On acceptance, the Minister shall issue a Resource Agreement to the ASO Corp, including the General Terms and Conditions, the Minister's special provisions, and the CMRDC terms and conditions. The agreement cannot be transferred. ${ }^{83}$

If the offer is not accepted, the Minerals become available for posting in a public offering (s 305(a)). In addition, "further Direct Purchase Requests for the same Minerals will not be accepted by the Minister for a period of time to be determined by the Minister" (s 305(b)). That is, the Minister has a means of deterring intransigence on the part of an ASO Corp.

\section{Assessment}

The 2013 CMA lies in the shadow of legal and economic uncertainties.

The legal uncertainties emerge from the Federal Court decision in Daniels. ${ }^{84}$ The Federal Court of Appeal has upheld Justice Phelan's determination that the Métis are included in the scope of the term "Indian" in s 91(24) of the Constitution Act, 1867. Parliament, then, has legislative authority respecting Métis matters. One uncertainty is whether the Federal Court of Appeal will be upheld by the Supreme Court; another is whether and how the Supreme Court's decision will change the legal landscape; yet another is whether Alberta's Métis legislation will be found to be ultra vires. ${ }^{85}$ Justice Phelan did not discuss the fate of Alberta's legislation. Fred Martin and Catherine Bell have argued, in connection with the original Accord process, that negotiations carried on in good faith - and in the context of very substantial consultation and discussion both between the Province and Métis representatives and within the Métis community - should be respected, if need be by federal legislation confirming provincial legislative outcomes. ${ }^{86}$

The economic uncertainties concern, on the one hand, oil and gas prices and production costs. Even if Métis Settlements are located on still significant resources, revenues depend on drilling activity, and drilling activity depends on the relative economic benefits of development on Métis lands. Attaching a dollar value to potential revenue streams is difficult. ${ }^{87} \mathrm{On}$ the other hand, there are economic uncertainties relating to Settlements' available capital budgets. ASO Corp's and Participation Options will require investment.

These uncertainties aside, the 2013 CMA promotes Métis Settlement self-sufficiency built on Land and Culture.

The "surface veto" spares Settlement lands from unwelcome development. The CMA grants Settlements stronger surface control than (e.g.) freehold non-Settlement owners. Not only are freeholders not consulted before posting, but if approval for a project is granted by the Alberta Energy Regulator, freeholders cannot block surface access through Surface Rights Board proceedings. ${ }^{88}$ Moreover, the CMA provides pre-posting intervention rights that are not otherwise (currently) accorded to any other aboriginal peoples in Alberta.

The new General Terms and Conditions and Benefit Proposal requirements strengthen the 
Settlements' position by eliminating uncertainty about matters to be dealt with through consultation or negotiation. The CMA imposes tight time lines, which should ensure focused negotiation. Moreover, the new "top 75\% bidder" consultation process puts competitive pressure on bidders to think through and properly resource Benefits Proposals. The Province - it is worth noting - is accepting the possibility of a discount on bonus (since not the top but one of the " $75 \%$ bidders" may succeed) or even the loss of bonus and royalties (since no deal may be made). Benefits provided by proponents should protect land and promote culture (environmental, socio-cultural, and land use impacts); and should ensure revenue streams that will support self-sufficiency (employment and business opportunities, Overriding Royalty or Participation Option). ${ }^{89}$ Moreover, removing the cap on the Participation Option percentage creates the opportunity for additional Settlement revenues through additional investment. It has been reported that "the vast majority of councils have taken advantage of the opportunity to invest that 25 per cent maximum. ${ }^{90}$ Funds permitting, the Settlements should be willing to invest more.

There are risks associated with participation in development. Development may damage the biophysical environment, including wildlife and fish habitats. The influx of oil dollars can create social stresses within communities. Oil-related jobs can draw people - especially young people - away from their communities. Participation in non-traditional industries could have a corrosive effect on traditional ways of life. ${ }^{91}$ All this may be conceded - but the CMA empowers the Settlements to decide whether and how they want to participate in development, and allows them to shape appropriate mitigation strategies.

A key feature of the 2013 CMA is that both the MSGC and ASC have roles. Affected Settlements should benefit since their people and lands are directly affected. The MSGC can ensure the reflection of all Settlements' perspectives in decision-making. It can express "the overriding community interest in all settlement lands." 92 Further, not all revenues flow to the ASC. The MSGC retains a portion of both Overriding Royalty revenues and Participation Option interests. The MSGC, then, can reduce "disparities between rich and poor Settlements." ${ }^{33}$

Métis Settlement federalism, though, also generates risks. For deals to come together, the MSGC and the ASC must reach consensus. If a common position cannot be developed, deals could be lost. Giving CMA-style rights to ASCs alone, without MSGC involvement, could have been more expeditious. But that is not what the Métis Settlements negotiated. Recall Ghostkeeper's words: "the manner in which this goal is eventually achieved is perhaps more important than the goal itself." 94 The CMA expresses a structure negotiated by the Settlements, embodying an approach appropriate to Métis culture in a mineral tenure management document. The Métis can work out any problems as a community, as they have worked as a community in Alberta since the 1930s, and as they have worked as communities in centuries past.

\section{Notes}

* Professor, Faculty of Law, University of Alberta. Many thanks to Frank Tough for his comments on a previous version of this paper. All inaccuracies and infelicities are my own. I have used the spelling "Metis" (no accent) to track quoted usage; otherwise, I have used "Métis".

1 Elmer Ghostkeeper, "Our Land and our Culture is our Future: Strategies and Implications of Development on the Metis Settlements of Alberta" (1981) 1 Canadian Journal of Native Studies 151 at 151-52 [Ghostkeeper].

2 Government of Alberta, News Release, "Alberta government and Metis settlements celebrate new development agreement" (16 May 2013) online: Government of Alberta <http://alberta. ca/acn/201305/34183ADF6A37A-9D60-5199ED9BBA9212F3B584.html > [Alberta Government News Release].

3 A hard copy of the 2013 CMA is on file with the writer. It is an amendment agreement, rather than a wholly new agreement. The terms of the 2013 CMA are outlined in Alberta Energy, Information Letter 2013-17, "Public Offering of Crown 
Petroleum and Natural Gas and Oil Sands Rights on Metis Settlements" (21 May 2013) online: Alberta Energy <http://inform.energy.gov.ab.ca/ Documents/Published/IL-2013-17.pdf> [IL 201317].

4 Metis Settlements Act, RSA 2000, c M-14 [MSA].

5 Alberta Government News Release, supra note 2.

6 Karen Kleiss, "Métis gain greater control over oil and gas on their lands", Edmonton Journal (16 May 2013) online: Edmonton Journal <http://www. edmontonjournal.com/M\%C3\%A9tis+gain+ greater+control+over+their+lands/8397694/story. html> [Kleiss].

7 Whether significant mineral resources remain beneath Settlement lands lies beyond the scope of this paper. I do note that Alberta's Métis Settlements - compared to many other Alberta locations have respectable resource development prospects. While the oil and gas resources in Settlement areas have been depleted by production since the 1960s, "[n]obody knows how much oil and gas is left under the settlements, but Métis officials say 40 per cent of settlement land has yet to be developed": Kleiss, supra note 6. Even lands that have been developed may yet hold promise. Less depletion of oil sands than conventional resources may have occurred because its production is more recent; and resources not recoverable decades ago may now be recoverable using modern techniques. Further, some Settlements may fall within areas supporting shale development.

8 For an account of the scrip system, see Frank Tough \& Erin McGregor, “The Rights To The Land May Be Transferred': Archival Records as Colonial Text - A Narrative of Metis Scrip" (2007) 34:1 Canadian Review of Comparative Literature 33; John Weinstein, Quiet Revolution West: The Rebirth of Métis Nationalism (Calgary: Fifth House, 2007) at 17-22; Fred Martin, "Alberta Métis Settlements[:] A Brief History" in Richard Connors \& John Law, eds, Forging Alberta's Constitutional Framework (Edmonton: The University of Alberta Press, 2005) 345 at 350-51 [Martin 2005].

9 Alberta (Aboriginal Affairs and Northern Development) v Cunningham, 2011 SCC 37 at para 7.

10 Report of the Royal Commission Appointed to Investigate the Conditions of the Half-Breed Population of Alberta (15 February 1936), online: University of Alberta Libraries <http:// royal.library.ualberta.ca/royalcommissions/ dspImage.cfm? $\mathrm{ID}=81 \&$ Current $=1>$ at 2-3 [Ewing Commission Report].
11 Foundations for the Future of Alberta's Metis Settlements: Report of the MacEwan Joint Committee to Review the Metis Betterment Act and Regulations to the Honourable JGJ Koziak, Minister of Municipal Affairs (12 July 1984) at 4 [MacEwan Committee Report]; Catherine Bell, Alberta's Metis Settlements Legislation: An Overview of Ownership and Management of Settlement Lands (Regina : Canadian Plains Research Center, University of Regina, 1994) at 2 [Bell, "Overview"].

12 Alberta Federation of Metis Settlement Associations, "By Means of Conferences and Negotiations" We Ensure Our Rights (Edmonton: July 1986) at 12-13 [AFMSA, "By Means of Conferences"]; Martin 2005, supra note 8 at 353; Fred Martin, "Federal and Provincial Responsibility in the Metis Settlements of Alberta" in David Hawkes, ed, Aboriginal Peoples and Government Responsibility: Exploring Federal and Provincial Roles (Ottawa: Carleton University Press, 1989) 243 at 254-55 [Martin 1989]; Bell, "Overview", supra note 11 at 2.

13 Ewing Commission Report, supra note 10. The Commission was established under the Public Inquiries Act by Order in Council of 12 December 1934 (30:24 A Gaz 941), following a Legislative Assembly resolution of 27 February 1933.

14 Martin 2005, supra note 8 at 354; Martin 1989, supra note 12 at 256-57.

15 Ewing Commission Report, supra note 10 at 14 (see also 9, 10), 18.

16 Ibid at 10, 12.

17 Ibid.

18 Ibid at $12,13$.

19 Ibid at 11.

20 SA 1938, c. 6.

21 RSA 1942, c. 329 s 1. See Martin 2005, supra note 8 at 360 .

22 See, in particular, amendments added by An Act to Amend and Consolidate the Metis Population Betterment Act, SA 1940 c 6, ss 10-11, 19.

23 Alta Reg 112/60.

24 Ibid.

25 "Since the establishment of the Settlements, our understanding has been that we are the owners of the land and resources:" Alberta Federation of Metis Settlement Associations, Metisism[:] A Canadian Identity (Edmonton: 30 June 1982) 1, 13, 17 [AFMSA, Metisism].

26 Poitras v Alberta (AG) (1969), 68 WWR 224, 1969 CarswellAlta 24 (Alta. SC) at para. 16 (CarswellAlta).

27 Ibid, paras. 54-56 (CarswellAlta). 
28 Incorporated as a non-profit society in 1975, it would become the MSGC.

29 AFMSA, "By Means of Conferences", supra note 12 at 4; Martin 2005, supra note 8 at 366, n 70.

30 Alberta, Office of the Ombudsman, A Report by the Provincial Ombudsman Dealing with the Removal of Files from Metis Settlements on Monday, June 18, 1979, (Edmonton: Office of the Ombudsman, 1979) at $6-7$ [Ombudsman Report].

31 Ibid at 1; Martin 2005, supra note 8 at 369; Martin 1989 , supra note 12 at 270.

32 Ombudsman Report, supra note 30 at 13-14, $17,21$.

33 Ibid at 17-18.

34 Established through Order in Council of 31 March 1982; see the MacEwan Committee Report, supra note 11 .

35 Ibid at 5.

36 Ibid at 34, 5.

37 AFMSA, "By Means of Conferences", supra note 12 at 9; Bell, "Overview", supra note 11 at 15.

38 Martin 2005, supra note 8 at 374-75; John Graham, "Working Paper \#2: Interview with Fred Martin on the Development of the Metis Settlement Governance System" in Advancing Governance of the Metis Settlements of Alberta: Selected Working Papers (Ottawa: Institute on Governance, 31 March 2007) 20 at 22, online: Métis Nation Gateway <http://www.metisportals.ca/cons/wp-content/ uploads/2009/02/advancing-governance-metissettlements-of-alberta.pdf> [Martin Interview].

39 Alberta Aboriginal Relations, AlbertaMetis Settlements Accord (1989), online: Alberta Aboriginal Relations <http://www. aboriginal.alberta.ca/documents/AlbertaMetis SettlementsAccord.pdf>; Martin Interview, supra note 38 at 20-21.

40 See Bell, "Overview", supra note 11 at 1.

41 Metis Settlements Accord Implementation Act, RSA 2000, c.M-15, ss 49-52 [MSAIA].

42 Ibid, Parts 1 and 3.

43 MSA, supra note 4, Parts 1 -2.

44 Ibid, Parts 8, 1; the eight settlements - Buffalo Lake, East Prairie, Elizabeth, Fishing Lake, Gift Lake, Kikino, Paddle Prairie, and Peavine: s 2(1).

45 See MSAIA, supra note 41, s 49; Constitution of Alberta Amendment Act, 1990, RSA 2000, c C-24 $[C A A A]$. For an example of letters patent reserving mines and minerals rights to the Province, see Bell, "Overview", supra note 11 at 112 (concerning the Paddle Prairie Métis Settlement Area).

46 CAAA, supra note 45.

47 The CMA applies to "minerals" as defined in the Mines and Minerals Act, RSA 2000, c M-17
[MMA] s 1(1)(p)(i) - "all naturally occurring minerals, and without restricting the generality of the foregoing, includes ... gold, silver, uranium, platinum, pitchblende, radium, precious stones, copper, iron, tin, zinc, asbestos, salts, sulphur, petroleum, oil, asphalt, bituminous sands, oil sands, natural gas, coal, anhydrite, barite, bauxite, bentonite, diatomite, dolomite, epsomite, granite, gypsum, limestone, marble, mica, mirabilite, potash, quartz rock, rock phosphate, sandstone, serpentine, shale, slate, talc, thenardite, trona, volcanic ash, sand, gravel, clay and marl."

There is an extensive literature respecting the varieties and risks of "co-management" arrangements, which I cannot explore here. See e.g. David Laidlaw \& Monique M Passelac-Ross, "Sharing Land Stewardship in Alberta: The Role of Aboriginal Peoples", CIRL Occasional Paper No. 38 (Calgary: Canadian Institute of Resources Law, 2012); Claudia Notzke, "A New Perspective in Aboriginal Natural Resource Management: Co-management" (1995) 26:2 Geoforum 187; Lars Carlsson \& Fikret Berkes, "Co-management: concepts and methodological implications" (2005) 75 Journal of Environmental Management 65; Marc Stevenson, “The Possibility of Difference: Rethinking Co-management” (2006) 65:2 Human Organization 167.

49 CMA rights supplement the consultation rights of the Métis as aboriginal people. Alberta's consultation process with Métis peoples is currently under review: Aboriginal Consultation Office, Aboriginal Consultation Office Qs and As, online: Alberta Aboriginal Relations <http://www. aboriginal.alberta.ca/573.cfm $>$; Shari Narine, "Government to work with Métis, industry on consultation policy" Alberta Sweetgrass (20:3, 2013), online: The Aboriginal Multi-Media Society <http://www.ammsa.com/publications/albertasweetgrass/government-work-m\%C3\%A9tisindustry-consultation-policy>; Shari Narine, "Co-management agreement to bring economic benefits for Métis settlements" Alberta Sweetgrass (20:7, 2013), online: The Aboriginal Multi-Media Society <http://www.ammsa.com/publications/ alberta-sweetgrass/co-management-agreementbring-economic-benefits-m\%C3\%A9tissettlements $>$. Further, If Métis people would be directly and adversely affected by development, they could seek to intervene in Alberta Energy Regulator proceedings: Responsible Energy Development Act, SA 2012, c R-17.3, s 32; Alberta Energy Regulator Rules of Practice, Alta Reg 99/2013, s 9. See Alberta Energy Regulator, 
Directive 056: Energy Development Applications and Schedules (1 September 2011), online: Alberta Energy Regulator <http://www.aer.ca/ documents/directives/Directive056.pdf>, s 2.1: "[a]ll requirements and expectations detailed in this section apply to personal consultation and notification with all potentially directly and adversely affected persons, including First Nations and Métis."

50 MMA, supra note 47, s 16(b): “...the Minister may issue an agreement in respect of a mineral or subsurface reservoir ... by way of sale by public tender conducted in a manner determined by the Minister ...."

51 Alta Reg 263/1997.

52 Alta Reg 196/2010.

53 See Alberta Energy, Petroleum \& Natural Gas Sales Frequently Asked Questions: Crown Petroleum and Natural Gas Rights, online: Alberta Energy <http:// www.energy.alberta.ca/Tenure/1096.asp > .

54 Alberta Energy, Information Letter 2007-21 "Crown Mineral Rights; Identification of Major Surface Concerns in Public Offering Notices" (27 June 2007) online: Alberta Energy <http:// inform.energy.gov.ab.ca/Published/IL-2007-21. pdf> [IL 2007-21]; Alberta Environment and Sustainable Resource Development, Crown Mineral Disposition, online: Alberta Environment and Sustainable Resource Development <http:// esrd.alberta.ca/lands-forests/land-management/ crown-mineral-disposition.aspx $>$.

55 Alberta Aboriginal Relations, The Government of Alberta's Policy on Consultation with First Nations on Land and Natural Resource Management, 2013, online: Alberta Aboriginal Relations $<$ http://www.aboriginal.alberta.ca/documents/ GoAPolicy-FNConsultation-2013.pdf $>$ at 3. The lack of pre-public offering consultation respecting developments on non-Settlement lands motivated the application for judicial review in Peavine Métis Settlement v Alberta (Energy), 2011 ABQB 472. See also Athabasca Chipewyan First Nation $v$ Alberta (Minister of Energy), 2011 ABCA 29.

56 Alberta Energy, Petroleum \& Natural Gas Public Offerings: Current Year, online: Alberta Energy $<$ http://www.energy.alberta.ca/Tenure/1314.asp $>$.

57 IL 2007-21, supra note 54.

58 Alberta Energy, Frequently Asked Questions for Direct Purchases: Crown Petroleum and Natural Gas Rights, online: Alberta Energy <http://www. energy.alberta.ca/Tenure/1097.asp > [Alberta Energy, Direct Purchase FAQs]; see also Alberta Energy, Direct Purchase Guide, online: Alberta
Energy <http://www.energy.alberta.ca/Tenure/ forms/dirpurguidepng.pdf $>$.

59 Alberta Energy, Direct Purchase FAQs, supra note 58.

60 Alberta Energy, Alberta Oil Sands Tenure Guidelines, online: Alberta Energy <http:// www.energy.alberta.ca/OilSands/pdfs/GDE_ OST_2009_Ch2.pdf >ch 2 at 2-13.

611990 CMA s 202; see Articles 2, 3 and 4 of the 1990 CMA.

62 Unless otherwise noted, all in-text references to sections will be to the 2013 CMA.

63 "In addition to the General Terms and Conditions, the Minister may also include in the Public Offering Notice any terms and conditions recommended by the Crown Mineral Disposition Review Committee:" 2013 CMA, s 207.

64 A proponent facing a no-surface recommendation should not be able to side-step the "surface veto" by applying for surface rights access under the MSA. MSGC and ASC consent are required to exploit Crown mineral rights under s 7(3) of the Metis Settlement Land Protection Act, RSA 2000, c M-16.. Moreover, the vetod proponent would not be eligible to apply for surface rights access, since it would not have an "authorized project" under $\mathrm{s}$ 111(a)(i) of the MSA, supra note 4.

65 If the MSGC fails to respond to a posting request within 15 days, the Minister may include the Minerals in a public offering, together with the General Terms and Conditions (2013 CMA, s 206).

66 MSGC, Land and Resources - Co-Management Agreement - CMA Terms and Conditions-Final, online: MSGC <http://www.msgc.ca/Assets/ documents/uploads/CMA\%20Terms\%20and\%20 Conditions\%20-\%20Final.pdf> [General Terms and Conditions]. Environmental, economic, and social impacts could also be considered through the environmental impact assessment process, should that process be engaged: Environmental Protection and Enhancement Act, RSA 2000, c E-12, s 49; and see s 40(c).

67 See ss 303 and 306-310 of the 1990 CMA. The 1990 CMA had inserted a layer of negotiation between the Minister and the Affected MSAC respecting terms and conditions. This process, which permitted a curious intrusion into Settlement affairs by the Minister, has been eliminated in the 2013 CMA.

68 Section 303 of the 1990 CMA had stated that “[a]n Affected MSAC may ... recommend terms and conditions" [emphasis added]. 
69 MSGC, Land and Resources - Co-Management Agreement- CMA Metis Settlements Benefits Proposal - Final, online: MSGC <http://www. msgc.ca/Assets/documents/uploads/CMA\%20 Met is \% 20 Settlement s $\% 20$ Benefit s $\% 20$ Proposal\%20-\%20Final.pdf> [Benefits Proposal].

70 General Terms and Conditions, supra, note 66; see IL 2013-17, supra note 3.

71 Benefits Proposal, supra note 70.

72 Policy GC-P0502, (2005) A Gaz I, 2180 at 2183, MSGC, online: MSGC Library - Policies <http:// www.msgc.ca/assets/documents/policy-oil_and_ gas_resource_sharing_policy.pdf $>$ [Resource Sharing Policy]. Resource revenues are paid into the Metis Settlements Consolidated Fund [MSC Fund]. Revenues for an ASC are paid into its Part 1 Settlement Account. The MSGC revenues are paid into a general oil and gas account in Part 1 of the MSC Fund. The MSGC may pay out money held in Part 1 of the MSC Fund in accordance with MSGC policy. An ASC may pay out funds in accordance with a settlement bylaw: ibid, ss 12- 14 .

731990 CMA, s 101(o).

74 Resource Sharing Policy, supra note 72.

75 Ibid s 6.

76 CMA 2013, s 101, definition of "Eligible Bidder," para. (a). See IL 2013-17, supra note 3: "If an eligible bidder is a corporation wholly owned by the settlement where the minerals are located, and is the highest bidder, that bid will be deemed the winning bid by Alberta Energy."

77 CMA 2013, s. 101, definition of "Eligible Bidder," para. (b): "a person, partnership, joint venture or any other business structure ... that has no legal or beneficial interest in Metis Settlement Lands, [and] ... in which a Settlement Corporation holds no interest, either directly or indirectly.").

78 CMA 2013, s. 101, definition of "Eligible Bidder," para. (b)(iii); see IL 2013-17, supra note 3.

79 See ss 501 and 502 of the 1990 CMA.

80 The CMA approach is consistent with the "joint negotiation" approach set out in the Resource Sharing Policy, supra note 72 at s 4.

81 "[T]he direct purchase option is available to corporations wholly owned by the Metis settlement for minerals located on their respective settlement lands only:" IL 2013-17, supra note 3; "[t]he direct purchase option is limited to corporations wholly owned by the settlement where the mineral rights are being requested. It is not available to other Metis owned corporations, or to any other corporations with a partial Metis interest": Alberta Energy, PNG Sales and Direct Purchase options on
Metis Lands, online: Alberta Energy <http://www. energy.alberta.ca/Tenure/3461.asp $>$.

82 Ibid.

83 IL 2013-17, supra note 3.

84 Daniels v Canada (Minister of Indian Affairs and Northern Development), 2013 FC 6, appeal allowed in part, 2014 FCA 101, Dawson JA (deleting reference in declaration to non-status Indians) [Daniels (FCA)].

85 See Bell, "Overview", supra note 11 at 76-78. Justice Dawson dismissed "speculative in terrorem arguments" that the inclusion of the Métis under s 91(24) "will make provincial legislation vulnerable to challenge;" and observed that "the power of one level of government to legislate in respect of a matter takes nothing away from the power of the other level to control another aspect within its own jurisdiction:" Daniels (FCA), supra note 84 at paras 149, 150.

86 Martin 1989, supra note 12 at 290; Bell, "Overview", supra note 11 at 76.

87 John Graham has indicated that the Settlements received about $\$ 80$ million in resource revenues (which I assume did not include spin-off or service industry-related revenues) between the inception of the CMA and the first quarter of 2005: John Graham, "Working Paper \# 1: Detailed Description of the Metis Settlements Governance System" in Advancing Governance of the Metis Settlements of Alberta: Selected Working Papers (Ottawa: Institute on Governance, 31 March 2007) 1 at 8, online: Métis Nation Gateway <http://www.metisportals. ca/cons/wp-content/uploads/2009/02/advancinggovernance-metis-settlements-of-alberta.pdf $>$.

88 Surface Rights Act, RSA 2000, c S-24, s 15(6); Windrift Ranches Ltd v Alberta (Surface Rights Board) (1986), 57 Alta LR (2d) 36 (Alta CA); Mueller v Montana Alberta Tie Ltd, 2011 ABQB 738.

89 "Developing this mixed economy requires large amounts of capital to which we haven't had access due to the denial of our right to subsurface resource revenues:" AFMSA, Metisism, supra note 25 at 49 . This "mixed economy" would include farming, ranching, hunting, fishing, and trapping: ibid.

90 Kleiss, supra note 6.

91 Laura Wright \& Jerry White, "Developing Oil and Gas Resources On or Near Indigenous Lands in Canada: An Overview of Laws, Treaties, Regulations and Agreements" (2012) 3:2 International Indigenous Policy Journal (article 5) 1 . 
92 AFMSA, "By Means of Conferences", supra note 12 at 6-7, quoting the Westlock Resolution, para 6.

93 MacEwan Committee Report, supra note 11 at 48; Ghostkeeper, supra note 1 at 155.

94 Ghostkeeper, supra note 1 at 151. 